Senarath, P.A.N.B. and Francis, M., 2021. Dispute avoidance from the perspective of procurement methods: A conceptual focus. In: Sandanayake, Y.G., Gunatilake, S. and Waidyasekara, K.G.A.S. (eds). Proceedings of the $9^{\text {th }}$ World Construction Symposium, 9-10 July 2021, Sri Lanka. [Online]. pp. 256-267. DOI: https://doi.org/10.31705/WCS.2021.22. Available from: https://ciobwcs.com/papers/

\title{
DISPUTE AVOIDANCE FROM THE PERSPECTIVE OF PROCUREMENT METHODS: A CONCEPTUAL FOCUS
}

\author{
P.A.N.B. Senarath ${ }^{1}$ and Mathusha Francis ${ }^{2}$
}

\begin{abstract}
Disputes are unavoidable in construction projects due to their complex characteristics and involvement of different parties, which can interrupt the smooth construction process. Hence, proper dispute avoidance strategies need to be implemented to avoid disputes beforehand. On the other hand, the previous researchers suggested that there is a link between disputes and procurement methods. Therefore, the current research investigates the disputes in the construction industry from the perspective of different procurement methods. A systematic literature review was carried out to identify the available procurement methods in the construction industry, disputes and dispute avoidance strategies and the features of the procurement methods from the perspective of disputes. Firstly, a total of fifty-two key research papers on the research area were employed to review. The literature findings revealed that the industry has moved towards collaborative approaches from the traditional procurement method with higher dispute frequency because as per the findings the likelihood of disputes seems less in the projects procured under collaboration. It further revealed that the inherent features of collaborative approach such as teamwork, relationships and mutual understanding give less prosper towards disputes. Therefore, the findings of the review conclude that the selection of collaborative procurement method at the early stages of a project can reduce the possibilities of disputes from the perspective of procurement methods.
\end{abstract}

Keywords: Construction industry; Disputes; Procurement methods.

\section{INTRODUCTION}

The construction industry is one of the major industries, which plays a vital role in the economy of any country (Illankoon et al., 2019). It has become more competitive and complex due to the increasing demands of the employers and the global economic downturn (Farooqui et al., 2012). A procurement method can be considered as a key stage that ensures the successful delivery of a construction project despite the challenges (Wang et al., 2018) and the selection of procurement methods depends on the goals and objectives set forth, cost, time and quality (Lædre et al., 2006). Further, the author pointed out that the methods used for the selection of procurement routes should be improved or otherwise it will overrun on cost, time and quality. Different types of procurement arrangements are available and each procurement method is consisted of advantages and disadvantages concerning the delivery of the project, dispute occurrence and selection of Dispute Resolution Mechanisms (DRM) (Mante et al., 2012).

\footnotetext{
${ }^{1}$ Department of Building Economics, University of Moratuwa, Sri Lanka, bhagyasenarath72@gmail.com

${ }^{2}$ Department of Building Economics, University of Moratuwa, Sri Lanka, mathushaf@uom.lk
} 
The disagreements between the parties in a project may later turn into disputes (Illankoon et al., 2019). Construction disputes have become a major impediment that affect the performance of a construction project, causing the contribution of various practices to avoid disputes (De Alwis et al., 2016). The actions, or inactions of the employer, contractor or other consultants are the main reasons for disputes (Farooqui et al., 2012). Disputes become expensive in terms of finances, personnel, time and opportunity costs, if they are not managed and resolved promptly (Farooqui et al., 2012) while damaging the contractual relationships between the parties (Illankoon et al., 2019). Hence, adherence to DRM is essential because the study by Li and Cheung (2019), indicated that a cleaner output of construction works could be obtained through efficient dispute management. Dispute management can be implemented at the early stage of a project to avoid and resolve the disputes effectively beforehand (Francis et al., 2017).

The practice utilised in the industry when a dispute occurs is either Alternative Dispute Resolution (ADR) or litigation process (De Alwis et al., 2016). However, according to the authors, the drawbacks of DRM in the practical application have paved the path to the dispute avoidance concept. Moreover, Mante et al. (2012) stated that the disputes in a project depend on how it is procured and also procurement method is a crucial factor considered in dispute avoidance (De Alwis et al., 2016). Yusof et al. (2011) indicated that the traditional procurement method has the highest rate for disputes due to its key features and the other innovative methods like design and build, management and partnering methods have the capability of reducing the disputes. On the other hand, the working atmosphere of collaborative approach can be useful to avoid disputes (Elhag et $a l ., 2020)$. Therefore, a link of the relationship between the procurement methods and the occurrence of the disputes can be identified especially in terms of dispute avoidance.

Nevertheless, available literature on construction disputes tends to give more attention to dispute resolution than dispute avoidance (Naji et al., 2020). Furthermore, the growth of complexity and competitiveness in the construction industry has gained a reputation for disputes in the last few years (Elhag et al., 2020) and different types of procurement methods have also developed with the evolvement of construction procurement (Oyegoke et al., 2009). Thus, with the time elapsed, the key features of each method may have varied as well as along with the occurrence of disputes and dispute avoidance strategies. Therefore, this research aims to identify the procurement methods used in the construction industry, dispute avoidance strategies to be implemented through the stages of a project and the features of the procurement methods from the perspective of disputes in order to avoid the possible disputes considering the procurement methods.

\section{RESEARCH METHODOLOGY}

Literature reviews in research are conducted for numerous purposes (Okoli and Schabram, 2010). Systematic literature review facilitates to conduct a study in a methodical manner minimising researchers' bias (Khallaf et al., 2018). Further, the authors stated that it provides higher reliability in establishing frameworks and consistency in data collection comparatively to other literature review methods. Moreover, a systematic literature review enables the researchers for an explicit and reproducible to collect and combine the existing knowledge and to develop a research gap and provides suggestions for further research (Ahmed et al., 2017). Therefore, adhering to this method, the current research reviews the procurement methods in the 
construction industry, disputes, dispute avoidance strategies and dispute avoidance from the perspective of procurement methods considering the features of each method.

A comprehensive literature review was carried out based on systematic literature review by referring reliable sources. The research mainly focuses on relevant sources published within the study area related to procurement methods, disputes and dispute avoidance and the findings are aligned accordingly in the sections. A total of fifty-two (52) articles were employed for the study. Sections 3 and 4 provides brief introductions about procurement and disputes respectively. Thereafter, dispute avoidance strategies are identified through the stages of a construction project as in section 5. Subsequently the features of procurement methods, especially in terms of causes of disputes, frequency of disputes and dispute avoidance strategies in each are presented in section 6.

\section{PROCUREMENT METHODS IN THE CONSTRUCTION INDUSTRY}

The procurement method is a key method which creates the client's pre-conditions to ascertain the objectives of a project successfully, preventing project failure and dissatisfaction of the client (Ratnasabapathy and Rameezdeen, 2010). Various procurement methods have advanced along with the development of new concepts and technologies Chanudha et al. (2017) and Mante et al. (2012) recognised them as traditional, integrated approaches, management-oriented and collaborative/relationshipbased methods. Ratnasabapathy et al. (2005) identified lump sum, measure and pay, and prime cost as the common variants of traditional method; design and build, package deal, turnkey, develop and construct, novated design and, build and concession contracts as in the integrated method. According to Rahmani et al. (2017), management-oriented method is mainly divided as management contracting and construction management while partnering, joint ventures, alliancing and voluntary agreements can be identified as arrangements of collaborative method (Ratnasabapathy et al., 2005).

Earlier, traditional method was the only available option where the architect designs the building and the contractor bids for the project referring the drawings (Joseph and Jayasena, 2008). The report by the Charted Institute of Building (CIOB, 2010) stated that the traditional method is the most understood process in the construction industry with its utilization over a long time period. Nevertheless, a high number of disputes can occur in this method due to its key features (Mante et al., 2012). McDermotti and Khalfan (2012), stated that recently, novel procurement methods are implemented to achieve more integrated and organised processes. Moreover, Naoum and Egbu (2016), stated that alternative procurement methods like design and build, management contracting and construction project management are introduced to overcome the problems from lack of integration, separation of design from construction, improper communication, uncertainty, changes in environment and client's expectations. Furthermore, Elhag et al. (2020) emphasised the use of collaborative approach due to its benefits as improved relationships and communication, better productivity and decrease of disputes and litigation. Moreover, change in attitudes and emphasis on trust are the guiding factors of dispute prevention scheme in collaborative method (Mante et al., 2012). 


\section{DISPUTES IN THE CONSTRUCTION INDUSTRY}

Disputes can be considered as a major factor obstructing the successful completion of a construction project due to its high cost and time consumption (Naji et al., 2020). Moreover, disputes are unavoidable because of the complexity, involvement of multiparties in a project (Abeynayake and Weddikkara, 2013), poor preparation of contract documents, inadequate planning, financial issues and communication issues (Farooqui et al., 2012). Disputes may arise from the commencement to the execution of works because both the parties constantly have to satisfy shared obligations on both sides and a single default case is sufficient to interrupt the balancing pendulum and the entire development (Pawar and Patil, 2014). Therefore, the findings by Farooqui et al. (2012), concluded that construction disputes shall be avoided and cautiously managed to obtain a smooth construction process as prevention of disputes is better than cure.

\section{DISPUTE AVOIDANCE STRATEGIES}

The disputes must be investigated thoroughly and as soon as possible to determine the causes of disputes and relate them to the pre-construction phase to reduce or eliminate them before the commencement of the construction (Naji et al., 2020). De Alwis et al. (2016) identified briefing stage, pre contract stage and post contract stage as the major stages in a construction project in preparation of a dispute avoidance model for the Sri Lankan construction industry. Hence, here the dispute avoidance strategies from 21 studies are categorized according to the above mentioned phases in Table 1.

Table 1: Dispute avoidance strategies

\begin{tabular}{lc}
\hline \multicolumn{1}{c}{ Dispute Avoidance Strategies } & Sources \\
\hline Briefing stage & {$[4],[19],[20]$} \\
Selection of most appropriate procurement method & {$[6],[7],[13],[16]$} \\
Selection of collaborative approach/partnering as & \\
procurement method & {$[4]$} \\
Specify the quality standards to follow & {$[4]$} \\
Assess the financial risks due to government policy & \\
changes & {$[2],[4],[19]$} \\
Pre-contract stage & {$[14],[15],[18]$} \\
Proper preparation of contract documents & \\
Intervention of an independent third party at the start of & {$[1],[8],[9],[10],[11]$,} \\
the contract [E.g.: Dispute Board (DB)/Dispute & {$[11]$} \\
Resolution Board (DRB)/Dispute Adjudication Board & {$[2],[3],[4],[7],[11],[21],[19]$} \\
(DAB)/Dispute Resolution Adviser (DRA)] & {$[17]$} \\
Implementation of proper dispute clauses in the contract & \\
Proper allocation of risks & {$[4]$} \\
Identify the link between the dispute's occurrence and & {$[13],[15]$} \\
pre-construction phase & {$[4]$} \\
Selection of contractors & \\
Early contractor involvement & \\
Time management by the contractors & \\
&
\end{tabular}




\begin{tabular}{|c|c|}
\hline Dispute Avoidance Strategies & Sources \\
\hline \multicolumn{2}{|l|}{ Post contract stage } \\
\hline Proper administration of contract documents & [19] \\
\hline Negotiating in an event of differentiating in matter & [3], [19] \\
\hline Early notification and resolution of the dispute & [19] \\
\hline Constructability & {$[13]$} \\
\hline Lean construction/Supply chain integration & {$[13]$} \\
\hline Stakeholder management alignment & [13] \\
\hline Use ADR filter mechanisms & {$[3],[11]$} \\
\hline Team building & {$[4],[6],[11],[15],[21]$} \\
\hline Role of the parties & {$[4]$} \\
\hline Study about occurrence and causes for disputes & {$[6],[15],[17]$} \\
\hline Quality assurance & {$[4]$} \\
\hline Improved relationships & {$[5],[6],[21]$} \\
\hline Patch perceptions of fairness & {$[6],[11],[21]$} \\
\hline \multicolumn{2}{|c|}{$\begin{array}{l}\text { [1] Abeynayake and Weddikkara (2013); [2] Cheung (2014); [3] Connerty (2006); [4] De } \\
\text { Alwis } \text { et al. (2016); [5] Chan and Suen (2005); [6] Elhag et al. (2020); [7] Gebken and Gibson } \\
\text { (2006); [8] Gerber (2001); [9] Hardjomuljadi (2020); [10] He (2010); [11] Jannadia et al. } \\
\text { (2000); [12] Jones (2006); [13] McGeorge et al. (2007); [14] MohdDanuri et al. (2016); [15 } \\
\text { Mosey (2019); [16] Mustaffa and Bowles (2004); [17] Naji et al. (2020); [18] Ong and Gerber } \\
\text { (2010); [19] Thusharika and Abeynayake (2016); [20] Yusof et al. (2011); [21] Zhu and } \\
\text { Cheung (2020) }\end{array}$} \\
\hline
\end{tabular}

The findings imply that dispute avoidance may commence from the preparation of contracts and selection of procurement methods as well. Appointment of a third party like a DB, DRB, DAB or DRA at the start of the contract is the most significant dispute avoidance method identified by most of the authors. Other than that, a balanced allocation of risks is also given priority by the researchers as a dispute avoidance strategy and it is important because according to De Alwis et al. (2016), construction related risks are one of the main causes of disputes. Furthermore, the selection of suitable procurement method, taking actions to improve the performance as a team and examining the dispute causes and clauses in the contract have a considerable effect on dispute avoidance.

Mante (2015) also identified several sets of dispute avoidance strategies which utilise procurement and management of relationships and, management related processes of construction projects. The findings of Table 1 have highlighted the selection of the most suitable procurement method and on the other hand, several authors recognised the collaborative/partnering approach itself as a method of dispute avoidance. The strategies such as team building, improved relationships and communication are also identified as dispute avoidance strategies by the authors which are the special characteristics of the collaborative approach as identified by Elhag et al. (2020). Moreover, the early involvement of the contractor is also identified as a dispute avoidance strategy where the focus again moves towards procurement methods because in management oriented, design and build, and collaborative methods early contractor involvement is clearly visible as per Table 2. Therefore, it can be identified that the selection of the proper procurement method has a huge impact on dispute avoidance as per the findings. Moreover, the collaborative approach has a significant impact on dispute avoidance in 
projects because most of the identified dispute avoidance strategies are recognisable as key features of the collaborative approach and several researchers recognised the method itself as a dispute avoidance strategy.

\section{FEATURES OF THE PROCUREMENT METHODS FROM THE PERSPECTIVE OF DISPUTES}

According to Rameezdeen and De Silva (2002), the construction procurement arrangements in the Sri Lankan context can be categorised as; separated systems (traditional method), integrated systems (design and build method), managementoriented systems and collaborative systems. Moreover, the features of the procurement systems may have different impacts on disputes and dispute avoidance. Therefore, the features of the procurement methods which are applicable in the Sri Lankan context, are illustrated in Table 2, elaborating the involvement of the parties, suitability of the method, early contractor involvement, causes of disputes, frequency of disputes and dispute avoidance strategies based on the literature findings.

Table 2: Features of procurement methods from the perspective of disputes

\begin{tabular}{|c|c|c|c|c|}
\hline & $\begin{array}{l}\text { Traditional } \\
\text { method }\end{array}$ & $\begin{array}{c}\text { Design and } \\
\text { build } \\
\text { method }\end{array}$ & $\begin{array}{c}\text { Management } \\
\text { oriented } \\
\text { method }\end{array}$ & $\begin{array}{c}\text { Collaborative/ } \\
\text { Partnering }\end{array}$ \\
\hline $\begin{array}{l}\text { Involvement } \\
\text { of parties }\end{array}$ & $\begin{array}{l}\text { Contractor is } \\
\text { selected after } \\
\text { the design is } \\
\text { completed } \\
\text { (Rahmani et al., } \\
\text { 2017). }\end{array}$ & $\begin{array}{l}\text { Contractor is } \\
\text { responsible for } \\
\text { both design } \\
\text { and } \\
\text { construction } \\
\text { (Teon, 2014). }\end{array}$ & $\begin{array}{l}\text { Entire process } \\
\text { is managed by } \\
\text { the contracted } \\
\text { consultant } \\
\text { (Rashid et al., } \\
\text { 2006). }\end{array}$ & $\begin{array}{l}\text { Collaboration } \\
\text { between the client } \\
\text { and the project } \\
\text { team (Mante } \text { et al., } \\
\text { 2012). }\end{array}$ \\
\hline Suitability & $\begin{array}{l}\text { Projects with } \\
\text { separate } \\
\text { responsibilities } \\
\text { for design and } \\
\text { construction } \\
\text { (Rashid et al., } \\
\text { 2006). }\end{array}$ & $\begin{array}{l}\text { Clients with } \\
\text { less experience } \\
\text { in design } \\
\text { (Lesniak et al., } \\
2012 \text { ). } \\
\text { Projects with } \\
\text { high priority in } \\
\text { buildability } \\
\text { (Naoum and } \\
\text { Egbu, 2015). }\end{array}$ & $\begin{array}{l}\text { Fast track } \\
\text { projects } \\
\text { (Sivkumaran } \\
\text { and Perera, } \\
\text { 2015) and } \\
\text { projects with } \\
\text { more } \\
\text { commercial } \\
\text { risk (Rahmani } \\
\text { et al., 2017) }\end{array}$ & $\begin{array}{l}\text { High risk and high } \\
\text { value projects } \\
\text { (Rameezdeen and } \\
\text { De Silva, 2002). } \\
\text { Any kind of } \\
\text { construction } \\
\text { project (CIOB, } \\
2010) \text {. }\end{array}$ \\
\hline $\begin{array}{l}\text { Early } \\
\text { contractor } \\
\text { involvement }\end{array}$ & $x$ & $\checkmark$ & $\checkmark$ & $\checkmark$ \\
\hline $\begin{array}{l}\text { Causes of } \\
\text { disputes }\end{array}$ & $\begin{array}{l}\text { 1.The } \\
\text { contractors tend } \\
\text { to reduce quality } \\
\text { by providing } \\
\text { lack of } \\
\text { buildability, } \\
\text { forcing design } \\
\text { alternations. }\end{array}$ & $\begin{array}{l}\text { 1.Dissatisfacti } \\
\text { on of the client } \\
\text { with the } \\
\text { quality and } \\
\text { design of the } \\
\text { final outcome. } \\
\text { 2.Abortive } \\
\text { work. }\end{array}$ & $\begin{array}{l}\text { 1. The absence } \\
\text { of single point } \\
\text { responsibility } \\
\text { for design and } \\
\text { construction } \\
\text { (CIOB, 2010). }\end{array}$ & $\begin{array}{l}\text { 1.Unforeseen } \\
\text { circumstances and } \\
\text { drawbacks (Sinha } \\
\text { and Jha, 2020). }\end{array}$ \\
\hline
\end{tabular}




\begin{tabular}{|c|c|c|c|c|}
\hline & $\begin{array}{l}\text { Traditional } \\
\text { method }\end{array}$ & $\begin{array}{l}\text { Design and } \\
\text { build } \\
\text { method }\end{array}$ & $\begin{array}{c}\text { Management } \\
\text { oriented } \\
\text { method }\end{array}$ & $\begin{array}{c}\text { Collaborative/ } \\
\text { Partnering }\end{array}$ \\
\hline & $\begin{array}{l}\text { 2.Contract } \\
\text { variations } \\
\text { (Elhag } \text { et al., } \\
\text { 2020). } \\
\text { 3.Lack of } \\
\text { communication. } \\
\text { 4.Price } \\
\text { competition. } \\
\text { 5.Fragmentation } \\
\text { (Mante } \text { et al., } \\
\text { 2012). } \\
\text { 6. Separation of } \\
\text { design and } \\
\text { construction } \\
\text { (CIOB, 2010) }\end{array}$ & $\begin{array}{l}\text { 3.Imprecisions } \\
\text { in the client's } \\
\text { brief. } \\
\text { 4.Conflicts } \\
\text { between the } \\
\text { brief and } \\
\text { contractor's } \\
\text { proposal. } \\
\text { 5.Valuation of } \\
\text { variations. } \\
\text { (Mante et al., } \\
\text { 2012). }\end{array}$ & & \\
\hline $\begin{array}{l}\text { Frequency of } \\
\text { disputes }\end{array}$ & $\begin{array}{l}\text { Higher } \\
\text { (Yusof et al., } \\
\text { 2011). }\end{array}$ & $\begin{array}{l}\text { Less. } \\
\text { (Mante et al., } \\
\text { 2012). }\end{array}$ & $\begin{array}{l}\text { Less } \\
\text { (Yusof et al., } \\
\text { 2011). }\end{array}$ & $\begin{array}{l}\text { Less. } \\
\text { (Mante et al., } \\
\text { 2012). }\end{array}$ \\
\hline $\begin{array}{l}\text { Dispute } \\
\text { avoidance } \\
\text { strategies }\end{array}$ & $\begin{array}{l}\text { Implement } \\
\text { alternative } \\
\text { procurement } \\
\text { methods as } \\
\text { design and build } \\
\text { and } \\
\text { collaboration } \\
\text { (Mante et al., } \\
\text { 2012). }\end{array}$ & $\begin{array}{l}\text { Early } \\
\text { involvement of } \\
\text { the contractor } \\
\text { (Elhag et al., } \\
2020 \text { ). } \\
\text { Implement } \\
\text { collaborative } \\
\text { method } \\
\text { (Mante } \text { et al., } \\
\text { 2012). }\end{array}$ & $\begin{array}{l}\text { Implement } \\
\text { collaborative } \\
\text { (partnering } \\
\text { and trust) } \\
\text { method } \\
\text { (Mehany et } \\
\text { al., 2018). }\end{array}$ & $\begin{array}{l}\text { The characteristics } \\
\text { of collaborative } \\
\text { method like social } \\
\text { relationships, non- } \\
\text { opportunistic } \\
\text { behaviour, trust, } \\
\text { faith, changing } \\
\text { attitudes and } \\
\text { respect among the } \\
\text { participants (Elhag } \\
\text { et al., 2020; Mante } \\
\text { et al., 2012). }\end{array}$ \\
\hline
\end{tabular}

The tabulated data of numerous studies indicate that the features of procurement methods vary with the type of the procurement method. The involvement of the contractor in traditional method occurs only after the design is completed, but the design and build contractor contributes from the early stages in both design and construction, improving the buildability. The appointed contractor in management-oriented method manages the total process while increasing the opportunity for more fast track and high risk projects. Collaborative arrangement is especially suitable for projects with high value and risks. However, the findings imply that irrespective of the implemented procurement method, disputes may arise due to various reasons. The traditional method is recognised as the method with the highest frequency for disputes while other methods have comparatively a less frequency. The reason for an increased number of disputes in traditionally procured projects is due to the main features of the procurement process (Mante et al., 2012) and as it is extensively subjected to variations, leading to an increase in cost and time extensions (Yusof et al., 2011). As per Table 2, several causes of disputes are identifiable in the traditional method due to issues like less quality, variations, lack of communication, 
separation of design and construction etc. In the design and build method as well disputes may arise with client's dissatisfaction with quality, ambiguities in the client's brief and the contractor's proposal, variation issues and abortive work. The main reason for disputes in management-oriented method is the lack of single point responsibility and unforeseen circumstances in collaborative approach. However, most of the researchers identified collaboration as a procurement method to avoid disputes successfully considering its key features and as collaboration between the project participants is claimed to lead for fewer disputes (Osipova and Eriksson, 2011). According to Table 2, the implementation of collaborative approach was significantly highlighted as a dispute avoidance strategy to be adopted under each procurement type.

However, the selection of the most suitable procurement method that is the most satisfactory to execute the works can avoid disputes (Thusharika and Abeynayake, 2016). As the costs related to adversarial relationships in the construction industry have become more obvious, collaborative practices began to emerge and interest in informal and less adversarial dispute resolution procedures have developed (Musonda and Muya, 2011). As per the findings, considerable attention towards the selection of collaborative approach is given to avoid disputes beforehand because its characteristics like social relationships, non-opportunistic behaviour, mutual trust, faith, changing attitudes and respect among the project participants have increased the consideration towards it. Figure 1 presents the conceptual framework derived through the findings of the study.

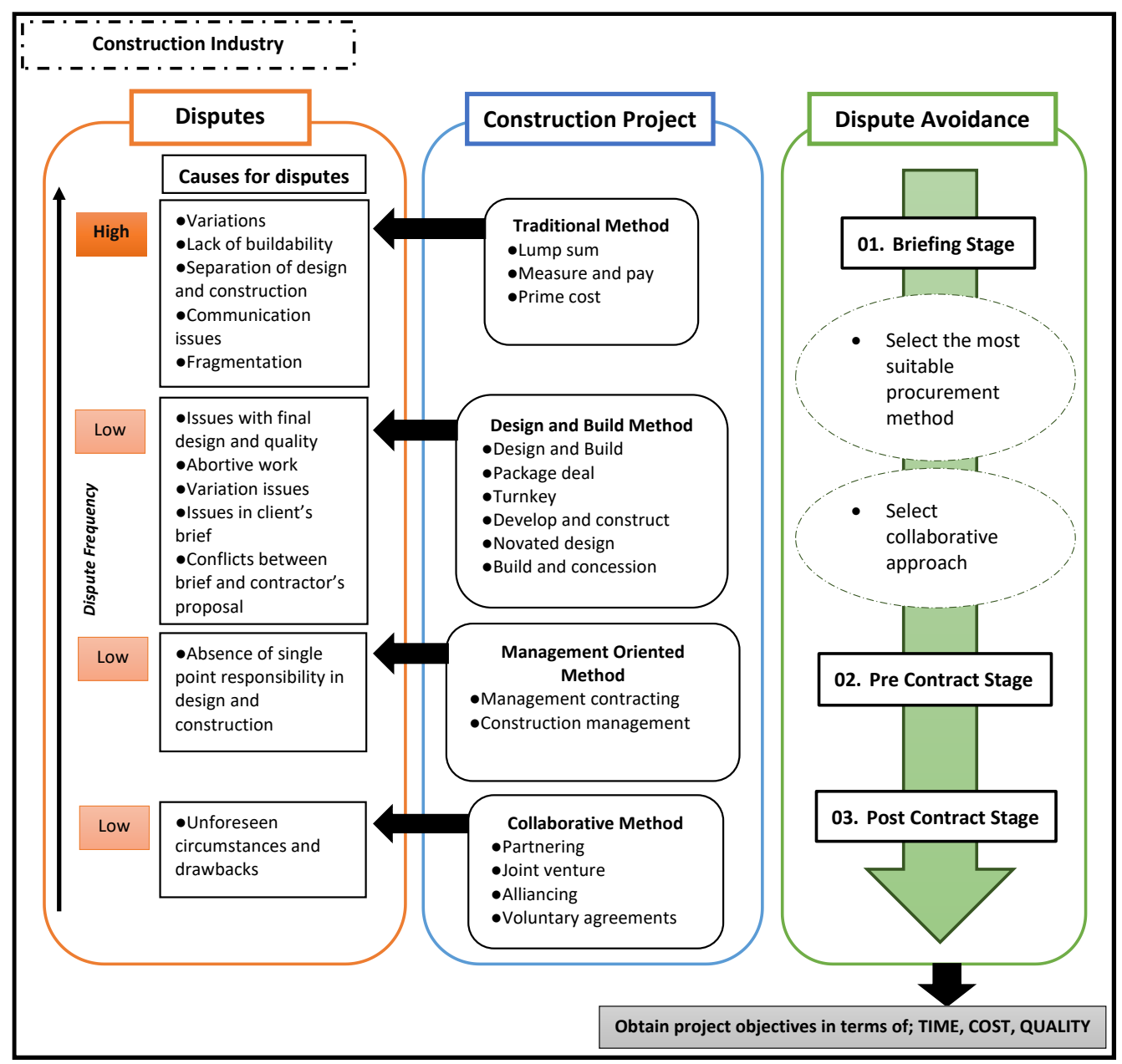

Figure 1: Conceptual framework for disputes from the perspective of procurement methods 
As per the developed framework, dispute avoidance can be initiated irrespective of the adopted procurement method in order to ensure the successful completion of a project while obtaining the objectives in terms of time, cost and quality. The procurement method with the highest rate for disputes is traditional method and the lowest is the collaborative method. Each method has various kinds of dispute causes which vary with the procurement type mainly because of the features of them. The causes of disputes respectively to each method is presented in the framework. On the other hand, dispute avoidance may take place at three major stages of a construction project: namely; briefing, pre contract and post contract stages. However, this research aims to elaborate the concept of dispute avoidance from the perspective of the procurement methods. According to the findings, selecting the most suitable procurement approach at the briefing stage acts as a dispute avoidance strategy and collaborative approach was mainly highlighted as a significant method with the capability of avoiding disputes. Disputes are inevitable irrespective of the used procurement type. Therefore, the industry practitioners must rethink of adopting dispute avoidance strategies from the commencement of the project, especially in terms of selecting a procurement method. Figure 1 clearly illustrates the key causes of disputes in each procurement method and the importance of selecting collaborative approach at the briefing stage. However, the developed model only identified the contextual aspects of dispute avoidance from the perspective of procurement methods and further investigations are required to ascertain the connection.

\section{CONCLUSIONS}

Disputes are common in construction projects because of the complex and competitive characteristics and involvement of different parties. If the disputes are not avoided or managed properly, it may affect the performance and the final outcome of a project. Hence, in the present competitive environment in the construction industry, the possibilities for disputes should be reduced and proper mechanisms should be implemented to reduce them. However, attention towards dispute avoidance should be high due to the disadvantages of DRM. Procurement method is a key factor which contributes to the successful completion of a project. Previous research pointed out that the method of how a project is procured contributes to the disputes that arise. Therefore, this study was conducted to further study the disputes in the construction industry from the perspective of procurement methods. A systematic literature survey was carried out by referring to reliable resources in the area of the research. The research identified the relationship between disputes and procurement methods in terms of the frequency of occurrence of disputes in each procurement method, causes for disputes and suitable dispute avoidance strategies for each method. The findings implied that in the traditional procurement method, dispute frequency is high compared to the other alternative methods mainly because the design and construction are separated. However, the research findings depict that disputes can be avoided by adopting the most suitable procurement method. Implementation of collaborative approach was highlighted to avoid the disputes beforehand and the discovered dispute avoidance strategies as well were included with the special characteristics of this method. The key features of it like improved relationships and communication, early contractor involvement, trust and understanding have the capability of dispute avoidance. The ability of collaborative approaches to avoid disputes from occurring is identified and proved in this research through the findings of previous research. Therefore, this research suggests that effective ways of dispute avoidance should be considered beforehand in every construction project, mainly by 
selecting a more collaborative procurement approach based on the findings. The findings of the study enable the industry practitioners to identify the features of the procurement methods which may cause and avoid the disputes and to recognise the dispute avoidance strategies which can be implemented throughout a construction project. The study can be further continued to develop a strategic framework to avoid disputes by investigating the causes of disputes and dispute avoidance strategies adopted in the projects procured under each procurement method, and the effects of disputes in each procurement method.

\section{REFERENCES}

Abeynayake, M. and Weddikkara, C., 2013. Special features and experiences of the full-term dispute adjudication board as an alternative dispute resolution method in the construction industry of Sri Lanka. In: International Conference on Building Resilience Heritance, Ahungalla 17-19 September 2013, pp. $1-14$.

Ahmed, A.L., Kawalek, J.P. and Kassem, M., 2017. A comprehensive identification and categorisation of drivers, factors, and determinants for BIM adoption: A systematic literature review. In: Computing in Civil Engineering 2017, Seattle, Washington 25-27 June 2017. American Society of Civil Engineers, pp. 220-227.

Chan, E.H. and Suen, H.C., 2005. Dispute resolution management for international construction projects in China. Management Decision, 43(4), pp. 589-602.

Chanudha, R., Disaratna, P., Anuruddika, S. and Ariyachandra, M., 2017. Procurement system selection model for the Sri Lankan construction industry. In: The $6^{\text {th }}$ World Construction Symposium 2017: What's New and What's Next in the Built Environment Sustainability Agenda?, Colombo 30 June - 02 July 2017. Ceylon Institute of Builders - Sri Lanka, pp. 162-173.

Cheung, S.O., 2014. Dispute avoidance through equitable risk allocation. In: Construction Dispute Research: Conceptualisation, Avoidance and Resolution. Cham: Springer International Publishing.

Connerty, A., 2006. A manual of international dispute resolution. London: Commonwealth Secretariat.

De Alwis, I., Abeynayake, M. and Francis, M., 2016. Dispute avoidance model for Sri Lankan construction industry. In: The 5th World Construction Symposium 2016: Greening Environment, Eco Innovations \& Entrepreneurship, Colombo 29-31 July 2016. Ceylon Institute of Builders - Sri Lanka, pp. 162-173.

Elhag, T., Eapen, S. and Ballal, T., 2020. Moderating claims and disputes through collaborative procurement. Construction Innovation, 20(1), pp. 79-95.

Farooqui, R. U., Masood, F. and Saleem, F., 2012. Key causes of construction disputes in Pakistan. In: Third International Conference on Construction in Developing Countries (ICCDC-III) "Advancing Civil, Architectural and Construction Engineering \& Management”, Bangkok 4-6 July 2012, pp. 7279.

Francis, M., Ramachandra, T. and Perera, S., 2017. Revisiting causes of disputes: perspectives of project participants, phases of project and project characteristics. In: The $5^{\text {th }}$ World Construction Symposium 2016: Greening Environment, Eco Innovations \& Entrepreneurship, Colombo 30 June - 02 July 2017. Ceylon Institute of Builders - Sri Lanka, pp. 368-376.

Gebken, R.J. and Gibson, G.E., 2006. Quantification of costs for dispute resolution procedures in the construction industry. Journal of Professional Issues in Engineering Education and Practice, 132(3), pp. 264-271.

Gerber, P., 2001. Dispute avoidance procedures (DAPs): The changing face of construction dispute management. In: The King's College Construction Law Association Construction Law 2000 Conference, London 5 June 2000. Australian Construction Law Newsletter, pp. 122-129.

Hardjomuljadi, S., 2020. Use of dispute avoidance and adjudication boards. Journal of Legal Affairs and Dispute Resolution in Engineering and Construction, 12(4), pp. 1-21.

He, X., 2010. A framework of dispute avoidance and resolution of construction project management. In: 2010 International Conference on Management and Service Science, MASS 2010, Wuhan 2010. IEEE, pp. 1-4. 
Illankoon, I.M.C.S., Tam, V.W.Y., Le, K.N. and Ranadewa, K.A.T.O., 2019. Causes of disputes, factors affecting dispute resolution and effective alternative dispute resolution for Sri Lankan construction industry. International Journal of Construction Management, pp. 1-11.

Jannadia, M.O., Assaf, S., Bubshait, A.A. and Naji, A., 2000. Contractual methods for dispute avoidance and resolution (DAR). International Journal of Project Management, 18(1), pp. 41-49.

Jones, D., 2006. Construction project dispute resolution: Options for effective dispute avoidance and management. Journal of Professional Issues in Engineering Education and Practice, 132(3), pp. 225235.

Joseph, A.L. and Jayasena, H.S., 2008. Impediments to the development of design and build procurement system in Sri Lanka. In: International Conference on Building Education and Research (BEAR), Cardiff 3-4 September 2008. School of the Built Environment, University of Salford, UK, pp. 1566-1575.

Khallaf, R., Kang, K. and Hastak, M., 2018. Analysis of the use of PPPs in higher education institutions through systematic literature review. In: Construction Research Congress 2018, New Orleans, Louisiana 2-4 April 2018. American Society of Civil Engineers, pp. 24-33.

Lædre, O., Austeng, K., Haugen, T.I. and Klakegg, O.J., 2006. Procurement routes in public building and construction projects. Journal of Construction Engineering and Management, 132(7), pp. 689-696.

Lesniak, A., Plebankiewicz, E. and Zima, K., 2012. Design and build procurement system: Contractor selection. Archives of Civil Engineering, 58(4), pp. 463-476.

Li, K. and Cheung, S.O., 2019. Alleviating bias to enhance sustainable construction dispute management. Journal of Cleaner Production, 249, pp. 1-32.

Mante, J., 2015. Resolving infrastructure-related construction disputes in developing countries: The Ghana experience. In: The 31 $1^{\text {st }}$ Annual Association of Researches in Construction Management Conference (ARCOM), Lincoln 7-9 September 2015. Association of Researchers in Construction Management, pp. 73-82.

Mante, J., Ndekugri, I., Ankrah, N. and Hammond, F., 2012. The influence of procurement methods on dispute resolution mechanism choice in construction. In: Proceedings of $28^{\text {th }}$ Annual Association of Researchers in Construction Management (ARCOM) Conference, Edinburgh 3-5 September. ARCOM, pp. 979-988.

McDermotti, P. and Khalfan, M., 2012. Achieving supply chain integration within construction industry. Construction Economics and Building, 6(2), pp. 44-54.

McGeorge, D., Love, P., Jefferies, M., Ward, P. and Chesworth, B., 2007. Dispute avoidance and resolution: A literature review. Brisbane: Cooperative Research Centre for Construction Innovation Authors.

Mehany, M.S.H.M., Bashettiyavar, G., Esmaeili, B. and Gad, G., 2018. Claims and project performance between traditional and alternative project delivery methods. Journal of Legal Affairs and Dispute Resolution in Engineering and Construction, 20(3), pp. 1-13.

MohdDanuri, M. S., Ishan, Z.M., Mustaffa, N.E., Bari, S., Karim, A., Mohamed, O. and Hanid, M., 2016. Dispute avoidance procedure: Formulating a workable legal system in the Malaysian construction industry. Journal of Design and Built Environment, 16(1), pp. 37-46.

Mosey, D., 2019. Collaborative construction procurement. $1^{\text {st }}$ ed. Cornwall: John Wiley \& Sons Ltd.

Musonda, H.M. and Muya, M., 2011. Construction dispute management and resolution in Zambia. Journal of Legal Affairs and Dispute Resolution in Engineering and Construction, 3(4), pp. 160-169.

Mustaffa, N.E. and Bowles, G., 2004. Dispute avoidance mechanism in partnering arrangements. In: $20^{\text {th }}$ Annual ARCOM Conference, Heriot Watt University 1-3 September 2004. Association of Researchers in Construction Managemen, pp. 721-730.

Naji, K.K., Mansour, M.M. and Gunduz, M., 2020. Methods for modeling and evaluating construction disputes: A critical review. IEEE Access, 8, pp. 45641-45652.

Naoum, S. and Egbu, C., 2015. Critical review of procurement method research in construction journals. Procedia Economics and Finance, 21(5), pp. 6-13.

Naoum, S.G. and Egbu, C., 2016. Modern selection criteria for procurement methods in construction. International Journal of Managing Projects in Business, 9(2), pp. 309-336.

Okoli, C. and Schabram, K., 2010. A guide to conducting a systematic literature. Sprouts: working Papers on Information, 10(26), pp. 1-49. 
Ong, B. and Gerber, P., 2010. Dispute boards: Is there a role for lawyers?. Construction Law International, 5(4), pp. 7-12.

Osipova, E. and Eriksson, P.E., 2011. How procurement options influence risk management in construction projects. Construction Management and Economics, 29(11), pp. 1149-1158.

Oyegoke, A.S., Dickinson, M., Khalfan, M.M., McDermott, P. and Rowlinson, S., 2009. Construction project procurement routes: An in-depth critique. International Journal of Managing Projects in Business, 2(3), pp. 338-354.

Pawar, O.A. and Patil, R.S., 2014. Conflicts \& disputes in construction projects. International Journal of Innovations in Engineering and Technology (IJIET), 3(3), pp. 48-53.

Rahmani, F., Maqsood, T. and Khalfan, M., 2017. An overview of construction procurement methods in Australia. Engineering, Construction and Architectural Management, 24(4), pp. 593-609.

Rameezdeen, R. and De Silva, S., 2002. Trends in construction procurement systems in Sri Lanka. Built Environment-Sri lanka, 02(02), pp. 2-9.

Rashid, R.A., Taib, I.M., Ahmad,W.B.W.A., Nasid, M.A., Ali, W.N.W.A. and Zainordin, Z.M., 2006. Effect of procurement systems on the performance of construction projects. In: Proceeding of International Conference on Construction Industry, Padang 21 - 24 June 2006. s.n., pp. 1-13.

Ratnasabapathy, S. and Rameezdeen, R., 2010. A decision support system for the selection of best procurement system in construction. Built Environment Sri Lanka, 7(2), pp. 43-53.

Ratnasabapathy, S., Rameezdeen, R. and Amaratunga, D., 2005. Macro analysis of construction procurement trends in Sri Lanka. In: $5^{\text {th }}$ International Postgraduate Research Conference (IPRC), Manchester 2005. pp. 525-536

Sinha, A.K. and Jha, K.N., 2020. Dispute resolution and litigation in PPP road projects: Evidence from select cases. Journal of Legal Affairs and Dispute Resolution in Engineering and Construction, 12(1), pp. 1-11.

Sivkumaran, S. and Perera, B.A.K.S., 2015. Construction management as a suitable procurement method for hotel building construction in Sri Lanka. In: 19 $9^{\text {th }}$ Pacific Association of Quantity Surveyors Congress, Yokohama 2015, pp. 1-15.

Teon, M., 2014. Project procurement method: The conflicts in construction projects procured under design and build method. Thesis. Universiti Malaysia Pahang

The Chartered Institute of Building (CIOB), 2010. A report exploring procurement in the construction industry, Ascot: s.n.

Thusharika, A. and Abeynayake, M., 2016. Framework for mitigating contractual disputes in the Sri Lankan construction industry. In: The $5^{\text {th }}$ World Construction Symposium 2016: Greening Environment, Eco Innovations \& Entrepreneurship, Colombo 29-31 July 2016. Ceylon Institute of Builders (CIOB), pp. 221-230.

Wang, K.W., Hsu, Y.Y., Yu, W.D. and Cheng, S.T., 2018. Determination of project procurement method with a graphical analytic model. Sustainability, 10(10), pp. 1-17.

Yusof, A.M., Ismail, S. and Chin, L.S., 2011. Procurement method as conflict and dispute reduction mechanism for construction industry in Malaysia. In: $2^{\text {nd }}$ International Conference on Construction and Project Management, Singapore 2011. IACSIT Press, pp. 215-219.

Zhu, L. and Cheung, S.O., 2020. Power of incentivization in construction dispute avoidance. Journal of Legal Affairs and Dispute Resolution in Engineering and Construction, 12(2), pp. 1-7. 